ISA

Arboriculture \& Urban Forestry 2016. 42(3): 170-180

\title{
Differential Environments Influence Initial Transplant Establishment Among Tree Species Produced in Five Container Sizes
}

\author{
Lauren M. Garcia-Chance, Michael A. Arnold, Geoffrey C. Denny, \\ Sean T. Carver, and Andrew R. King
}

\begin{abstract}
Effects of two post-transplant environments were tested on trees grown in five nursery container sizes to determine differences in initial post-transplant growth. Vitex agnus-castus L., Acer rubrum L. var. drummondii (Hook. \& Arn. ex Nutt.) Sarg., and Taxodium distichum (L.) Rich. grown in 3.5 L (\#1), 11.7 L (\#3), 23.3 L (\#7), 97.8 L (\#25), and 175.0 L (\#45) containers were transplanted in early summer into field plots in College Station, Texas, and Starkville, Mississippi, U.S. Height, trunk diameter, and canopy width measurements were recorded after nursery production and the end of the first growing season to determine initial growth during landscape establishment. Growth of $A$. rubrum and $T$. distichum were significantly $(P \leq 0.05)$ affected by interactions among container sizes and environments, while $V$. agnus-castus did not demonstrate a difference between environments but were affected by container sizes. Across all species and locations, trees transplanted from smaller container sizes exhibited a greater percent change in growth than the larger container-size trees. Greater percent change in growth measures in the smaller container-size trees during the first growing season may indicate a more rapid establishment time compared to trees from larger containers. Where differential responses to environments occurred, predominantly the beneficial effects of smaller container sizes on post-transplant establishment were accentuated with more stressful establishment conditions.

Key Words. Acer rubrum; Bald Cypress; Chaste Tree; College Station; Mississippi; Red Maple; Starkville; Taxodium distichum; Texas; Vitex agnus-castus.
\end{abstract}

Nurseries have produced trees in larger container sizes to provide more immediate impacts in the landscape (Arnold 2004; Watson 2004); even large box stores (e.g., Walmart ${ }^{\oplus}$, Lowe's ${ }^{\circledR}$, and The Home Depot $^{\circledR}$ ) now sell trees in up to $378.6 \mathrm{~L}$ containers. While debate continues over the relative merits of different container sizes (Watson 2004), this could in part be due to the appreciation landscape industries and homeowners have for the instant impact large trees can provide, such as greater aesthetic value of larger trees (Kalmbach and Kielbaso 1979; Schroeder 2006), greater biomass present to withstand environmental anomalies (Nowak et al. 2007), less potential for accidental or malicious mechanical damage (Missouri Botanical Garden 2015), instant shade (Kalmbach and Kielbaso 1979; Schroeder et al. 2006), and increase in property value (Maco and McPherson 2003). However, larger trees cost more to grow and occupy a greater amount of nursery space, resulting in higher prices for consumers (Watson and Himelick 2013).

Smaller container sizes are less expensive for consumers because nurseries expend less materials and labor, save on inventory carrying costs by gaining more rapid turnover, and require less space $\left(\mathrm{m}^{2}\right)$ to produce smaller trees. Smaller container sizes, once transplanted to the field, may exhibit reduced transplant shock (Lauderdale et al. 1995), are in a phase of growth more closely aligned with the exponential growth rate of young seedlings (Gilman and Beeson 1996), and have been in containers for shorter periods prior to transplant. Additionally, they have been sequentially transplanted to larger containers fewer times, potentially reducing the chances of circling root development (Gilman and Kane 1990), and their smaller size makes for easier handling and staking (Watson and Himelick 2013). The benefits and 
costs of varying container sizes have yet to be fully evaluated to determine which container size affords the most advantageous opportunity to consumers.

Although container size establishment has been considered by several researchers (Gilman et al. 1998; Struve 2009; Gilman and Masters 2010; Gilman et al. 2010; Lambert et al. 2010; Gilman et al. 2013), extensive research has yet to be conducted, especially in regards to differences across environments. With trees being offered to the public in an ever-increasing array of sizes, it is important to determine the initial growth responses of various container-grown trees for different landscape environments. Geography influences trees' responses to varying light levels, photoperiods, and precipitation (Teskey and Hinckley 1986; Chapin et al. 1987), thus impacting the type of trees that can be grown (Abrams and Kubiske 1990). It is often generally accepted that smaller-sized planting stock establishes more quickly after transplanting than larger stock (Struve 2009; Gilman et al. 2010; Gilman et al. 2013). Lambert et al. (2010) investigated three sizes of containers for three species in forestry conditions, but only smaller sizes were tested [i.e., $3.5 \mathrm{~L}(\# 1)$, $11.7 \mathrm{~L}$ (\#3), and 23.3 L (\#7)], and no information was provided relative to the genotypic background of the plants-and so size may have been confounded with genotypes or nursery production conditions.

The purpose of this study was to determine if differential growth rates existed during the first year of establishment in the landscape with trees representing various ornamental landscape species grown in a wide range of container sizes, and if those initial post-transplant growth responses varied between two contrasting locations.

\section{MATERIALS AND METHODS}

Clonal selections of Vitex agnus-castus L. (spreading multi-stemmed small tree), Acer rubrum L. var. drummondii (Hook. \& Arn. ex Nutt.) Sarg. (singlestemmed deciduous broadleaved shade tree), and Taxodium distichum (L.) Rich. (single-stemmed deciduous conifer) were chosen due to their wide-spread use in the regional nursery trade and their representation of a variety of classes of landscape trees. In order to best represent contrasting environments that utilize all three species regularly in the landscape, two U.S. locations were selected; College Station, Texas (seasonally xeric) and Starkville, Mississippi (mesic).
Beginning spring 2011, tip cuttings $(8-10 \mathrm{~cm}$ long) of Acer rubrum var. drummondii 'Maroon', Vitex agnus-castus (unnamed white flowering clone), and Taxodium distichum (Test Clone TX8DD38) were taken from containerized clonal sources maintained in College Station, Texas, U.S. The basal end of these cuttings was then dipped in a liquid rooting hormone containing indolebutyric acid (IBA): naphthalene acetic acid (NAA) at a 3:1 concentrate $\left(2,500 \mathrm{mg} \bullet \mathrm{L}^{-1} \mathrm{IBA} / 1,250 \mathrm{mg} \bullet \mathrm{L}^{-1} \mathrm{NAA}\right)$ to water ratio for five seconds (Dip 'n Grow ${ }^{\otimes}$ Inc., Clackamas, Oregon, U.S.). Cuttings were placed in $36 \mathrm{~cm} \times 51 \mathrm{~cm} \times 10 \mathrm{~cm}$ deep flats (Kadon Corp., Dayton, Ohio, U.S.) filled with coarse perlite (Sunshine Perlite \#3 4cf SUGRPLITE Sun Gro Horticulture Canada LTD, Seba Beach, Alberta, Canada) on an intermittent mist bench in a poly-covered greenhouse. Intermittent mist was applied at 16 minute intervals for 20-second durations using reverse osmosis water from one hour before sunrise to one hour after sunset. Rooted cuttings were then potted in $3.5 \mathrm{~L}$ (\#1) black plastic pots (Nursery Supplies, Inc., Kissimmee, Florida, U.S.) containing Metro-Mix 700 media (Sun Gro Horticulture Canada Ltd, Vancouver, British Columbia, Canada).

Nurserymen used ANSI Z60.1 container class standards (American Association of Nurseryman 2004) caliper and height to determine the appropriate container size for individual trees (Table 1). Therefore, as the cuttings grew, trees were transplanted to successively larger container sizes, 11.7 L (\#3), 23.3 L (\#7), 97.8 L (\#25), and 175.0 L (\#45) when trees reached appropriate size for the current container (Figure 1). This process was repeated throughout a two-year period until 18 trees of each container size for each species were produced, with initial trees being transplanted to \#45 at nearly the same time propagation of cuttings for the \#1 containers began. During the repotting process, trees were removed from their initial container, roots were broken up by hand to disrupt circling roots, and trees were repotted in appropriate sized black plastic pots (Nursery Supplies, Inc., Kissimmee, Florida, U.S.) containing Metro-Mix 700 media (Sun Gro Horticulture Canada Ltd, Vancouver, British Columbia, Canada). As trees were produced, they were amended with $15 \mathrm{~N}-3.9 \mathrm{P}-9.9 \mathrm{~K}$ controlled release fertilizer (Osmocote ${ }^{\oplus}$ Plus, Scotts Co., Marysville, Ohio, U.S.) every spring 
and fall at $6.53 \mathrm{~kg} \bullet \mathrm{m}^{3}$ and grown in full sun in a gravel-bottom nursery in College Station, Texas, (lat. $30^{\circ} 37^{\prime} 45^{\prime \prime} \mathrm{N}$, long. $96^{\circ} 20^{\prime} 34^{\prime \prime} \mathrm{W}$ ). When all container sizes were obtained in June 2013 (Table $2)$, six trees of each container size for each species (90 total) were randomly selected and transplanted into field conditions in both College Station,

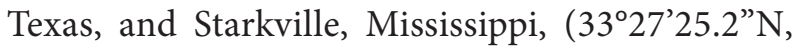
$\left.88^{\circ} 47^{\prime} 45.0^{\prime \prime} \mathrm{W}\right)$ using the methods of Watson and Himelick (2013). The remaining six trees were used to garner end of nursery production data.

\section{College Station, Texas}

Trees were transplanted to field plots 13-17 June 2013 in a completely randomized design with each species being a separate but concurrent experiment in adjacent plots. Spacings were $6 \mathrm{~m}$ in a row and $7.3 \mathrm{~m}$ between rows, with a total of four rows for each species. Soil was a sandy clay loam ( $66 \%$ sand, $8 \%$ silt, $26 \%$ clay, $6.0 \mathrm{pH})$. No fertilizer was applied after planting.

For the College Station location, under each tree, two Dan PC Jet spray stakes with a 18.9 L per hour flow (NaanDanJain Irrigation, Inc., Pasco, Washington, U.S.) were connected to a polyethylene round tubing irrigation system (The Toro Company, El Cajon, California, U.S.). Spray stakes were placed near the trunk and positioned outward with a $1.5 \mathrm{~m}$ spray radius. Five separate irrigation systems were installed for each species (15 total), in order to permit differential irrigation timing and quantity for each container size. Irrigation was conducted on a species by species and container-size by container-size (within species) basis, according to soil moisture levels determined using $30.5 \mathrm{~cm}$ soil moisture tensiometers (Spectrum Technologies, Inc., Aurora, Illinois, U.S.) installed at the edge of the root ball of one specimen of each container size of each species at a depth of $28.5 \mathrm{~cm}$. Water was applied when tensiometers indicated a $-20 \mathrm{kPa}$ (a soil moisture tension determined to equate with incipient wilting) until it returned to $>-1 \mathrm{kPa}$ of tension.

\section{Starkville, Mississippi}

Trees were obtained from College Station, Texas, in early June 2013 and transported to Starkville using a flatbed trailer and truck bed. All trees were covered with polyurethane tarps and secured using rope and cinch straps.

Table 1. ANSI Z60.1 container class standards by height and caliper. The standards are published in Imperial units; conversions to SI: 1 inch $=2.54 \mathrm{~cm}, 1$ foot $=0.305 \mathrm{~m}$.

\begin{tabular}{|c|c|c|c|c|c|c|}
\hline \multicolumn{2}{|l|}{ Types $1 \& 2$ shade trees } & \multicolumn{2}{|c|}{ Types 3 \& 4 small, upright, and spreading trees } & \multicolumn{2}{|c|}{ Shrub form and multi-stem trees } & \multirow{2}{*}{$\begin{array}{l}\text { Container } \\
\text { class }(\#)\end{array}$} \\
\hline $\begin{array}{l}\text { Minimum plant size } \\
\text { (height/caliper) }\end{array}$ & $\begin{array}{l}\text { Maximum plant size } \\
\text { (height/caliper) }\end{array}$ & $\begin{array}{l}\text { Minimum plant size } \\
\text { (height/caliper) }\end{array}$ & $\begin{array}{l}\text { Maximum plant size } \\
\text { (height/caliper) }\end{array}$ & $\begin{array}{l}\text { Minimum plant } \\
\text { size (height) }\end{array}$ & $\begin{array}{l}\text { Maximum plant } \\
\text { size (height) }\end{array}$ & \\
\hline 12 inch & 4 feet & 12 inches & 3 feet & $\mathrm{N} / \mathrm{A}$ & $\mathrm{N} / \mathrm{A}$ & 1 \\
\hline 2 feet & 6 feet & 18 inches & 4 feet & $\mathrm{N} / \mathrm{A}$ & $\mathrm{N} / \mathrm{A}$ & 2 \\
\hline 3 feet & 6 feet & $2 \frac{1}{2}$ feet & 6 feet $/ 1$ inch & 2 feet & 5 feet & 3 \\
\hline 4 feet & 7 feet & 4 feet & 7 feet $/ 1 \frac{1}{4}$ inches & 3 feet & 6 feet & 5 \\
\hline 5 feet & 8 feet $/ 1^{1 / 4}$ inch & 5 feet & $11 / 2$ inches & 4 feet & 7 feet & 7 \\
\hline 6 feet & $1 \frac{1 / 2}{2}$ inch & 6 feet $/ 3 / 4$ inch & $13 / 4$ inches & 5 feet & 8 feet & 10 \\
\hline 8 feet $/ 3 / 4$ inch & 2 inches & 1 inch & 2 inches & 6 feet & 10 feet & 15 \\
\hline 1 inch & $2 \frac{1}{2}$ inches & $1 \frac{1 / 4}{\text { inches }}$ & $2 \frac{1}{2}$ inches & 7 feet & 12 feet & 20 \\
\hline $1 \frac{1 / 4}{\text { inches }}$ & 3 inches & $11 / 2$ inches & 3 inches & 8 feet & 14 feet & 25 \\
\hline $13 / 4$ inches & $3 \frac{1}{2}$ inches & 2 inches & $31 / 2$ inches & 10 feet & 16 feet & 45 \\
\hline 2 inches & 4 inches & $21 / 2$ inches & 4 inches & 12 feet & 18 feet & 65 \\
\hline $2 \frac{1}{2}$ inches & 5 inches & 3 inches & 5 inches & 14 feet & 20 feet & $95 / 100$ \\
\hline
\end{tabular}

Table 2. Transplant height and trunk diameter sizes of Acer rubrum var. drummondii 'Maroon', Vitex agnus-castus, and Taxodium distichum at the end of container nursery production prior to transplant to the field sites for in-ground testing.

\begin{tabular}{|c|c|c|c|c|c|c|}
\hline \multirow{2}{*}{$\begin{array}{l}\text { Container } \\
\text { size }(\#)\end{array}$} & \multicolumn{2}{|l|}{ Acer rubrum } & \multicolumn{2}{|c|}{ Taxodium distichum } & \multicolumn{2}{|c|}{ Vitex agnus-castus } \\
\hline & $\begin{array}{l}\text { Mean trunk } \\
\text { diameter }(\mathrm{cm})\end{array}$ & $\begin{array}{l}\text { Mean } \\
\text { height }(\mathrm{cm})\end{array}$ & $\begin{array}{l}\text { Mean trunk } \\
\text { diameter }(\mathrm{cm})\end{array}$ & $\begin{array}{l}\text { Mean } \\
\text { height }(\mathrm{cm})\end{array}$ & $\begin{array}{l}\text { Mean canopy } \\
\text { spread }(\mathrm{cm})\end{array}$ & $\begin{array}{l}\text { Mean } \\
\text { height } \mathrm{cm} \text { ) }\end{array}$ \\
\hline 1 & - & - & $0.4 \pm 0.1 z$ & $37.0 \pm 6.1^{z}$ & $55.5 \pm 9.8^{z}$ & $54.7 \pm 7.9^{z}$ \\
\hline 3 & $0.9 \pm 0.1^{\mathrm{z}}$ & $114.3 \pm 10.9^{\mathrm{z}}$ & $0.8 \pm 0.1$ & $52.2 \pm 5.0$ & $73.2 \pm 4.0$ & $76.8 \pm 8.1$ \\
\hline 7 & $1.7 \pm 0.2$ & $188.0 \pm 15.6$ & $1.4 \pm 0.1$ & $105.3 \pm 6.5$ & $119.0 \pm 9.5$ & $135.5 \pm 23.4$ \\
\hline 25 & $4.1 \pm 0.1$ & $348.5 \pm 20.6$ & $3.3 \pm 0.2$ & $194.2 \pm 8.2$ & $224.7 \pm 19.6$ & $200.8 \pm 14.5$ \\
\hline 45 & $5.5 \pm 0.3$ & $411.7 \pm 22.5$ & $4.6 \pm 0.3$ & $245.5 \pm 8.1$ & $274.5 \pm 33.2$ & $266.2 \pm 19.6$ \\
\hline
\end{tabular}

${ }^{z}$ Values within a column represent the mean of six observations \pm standard errors; dash $(-)=$ could not be estimated. 


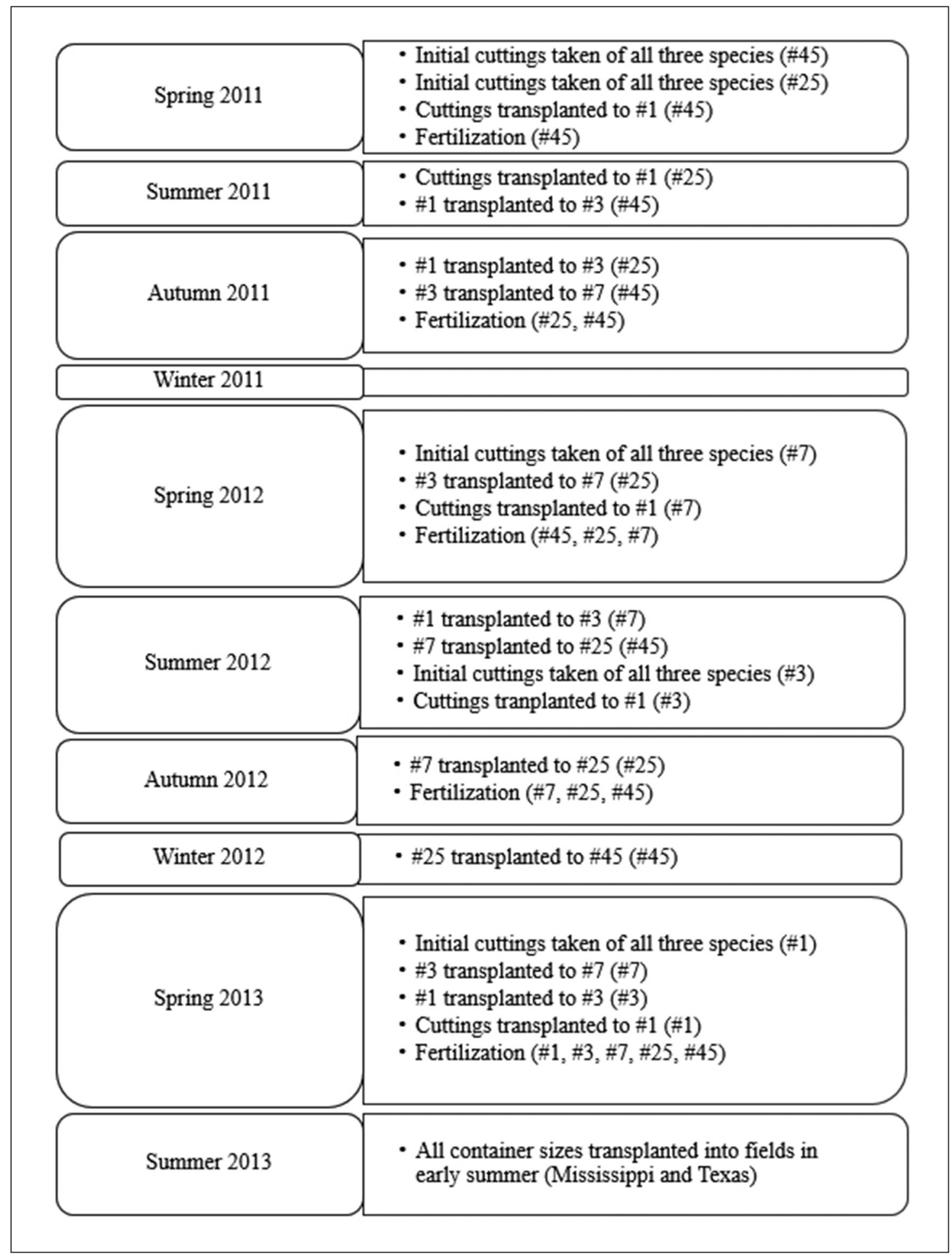

Figure 1. Timeline of propagation, transplant, and fertilization spring 2011 through summer 2013.

Damage due to transport was minimal (minor leaf loss) to non-existent for all trees. In Starkville, the trees were laid out in a completely randomized design with each species being a separate but concurrent experiment in adjacent plots. Trees were planted 13-17 June 2013 on $6 \mathrm{~m}$ centers in a silty clay loam soil ( $\mathrm{pH}$ 6.7). No fertilizer was applied after planting. 
Table 3. Comparison of 2013 weather conditions between College Station, Texas, and Starkville, Mississippi.

\begin{tabular}{|c|c|c|c|c|}
\hline \multirow[t]{2}{*}{ Month } & \multirow[t]{2}{*}{ Location } & \multicolumn{2}{|l|}{ Temperature } & \multirow{2}{*}{$\begin{array}{l}\text { Total monthly } \\
\text { precipitation }(\mathrm{cm})\end{array}$} \\
\hline & & $\begin{array}{l}\text { Mean } \\
\text { maximum }\left({ }^{\circ} \mathrm{C}\right)\end{array}$ & $\begin{array}{l}\text { Mean } \\
\text { minimum }\left({ }^{\circ} \mathrm{C}\right)\end{array}$ & \\
\hline \multirow[t]{2}{*}{ June } & Starkville & 31.8 & 18.8 & 7.1 \\
\hline & College Station & 35.0 & 22.8 & 3.3 \\
\hline \multirow[t]{2}{*}{ July } & Starkville & 31.7 & 18.5 & 10.2 \\
\hline & College Station & 35.6 & 23.6 & 3.6 \\
\hline \multirow[t]{2}{*}{ August } & Starkville & 32.4 & 18.8 & 5.8 \\
\hline & College Station & 37.4 & 23.9 & 2.0 \\
\hline \multirow[t]{2}{*}{ September } & Starkville & 31.3 & 17.5 & 12.4 \\
\hline & College Station & 34.3 & 22.4 & 13.2 \\
\hline \multirow[t]{2}{*}{ October } & Starkville & 23.5 & 10.6 & 8.1 \\
\hline & College Station & 26.8 & 15.4 & 23.1 \\
\hline \multirow[t]{2}{*}{ November } & Starkville & 15.7 & 2.3 & 13.0 \\
\hline & College Station & 18.4 & 8.4 & 11.7 \\
\hline
\end{tabular}

The Starkville field was not irrigated; instead, it was dependent on natural rainfall given that the monthly rainfall levels exceed those of College Station by roughly three times during the summer months (Table 3). Natural rainfall was not supplemented with irrigation at the Mississippi site.

No mulch was applied to either site. Overseeding with seasonal grasses between tree rows occurred and grass was kept mowed. To prevent root competition at the base of the tree, a $41 \%$ glyphosate herbicide (Martin's, Control Solutions Inc., Pasadena, Texas, U.S.) was applied to weeds within the tree drip line as needed to prevent root competition from weeds or grass.

Tree height and trunk diameter were measured in the nursery and at the end of the first growing season, 5-7 November 2013. Height was obtained by measuring from the substrate surface or root collar of the trunk to the apex of the canopy. Trunk diameter was taken at $15 \mathrm{~cm}$ from the substrate surface (American Association of Nurseryman 2004) rather than breast height (DBH) due to the size of trees from the smaller containers. Canopy width of $V$. agnus-castus was measured in two directions using the widest canopy diameter, then perpendicular to that transect. The average of the two widths was then calculated. The percent change was calculated between the pre- and post-transplant measurements as:

$$
\% \text { Change }=\left[\left(\mathrm{M}_{\text {Post }}-\mathrm{M}_{\mathrm{Pre}}\right) / \mathrm{M}_{\mathrm{Pre}}\right] \cdot 100
$$

Data were analyzed with statistical software (JMP 2009 and SAS 9.3, SAS Institute Inc., Cary, North Carolina, U.S.) using ANOVA to determine the significance $(P \leq 0.05)$ of interactions and main effects for each species independently. Where interactions were not significant, observations were pooled to test main effects. When significant effects were found, regression analyses were used to predict significant differences $(P \leq 0.05)$ within the range of tested levels of quantitative data. Means were compared using least-squares means procedures for discreet data with significant main effects of location.

\section{RESULTS AND DISCUSSION}

\section{Acer rubrum}

Interactions among container sizes and locations were significant $(P \leq 0.05)$ for end-of-season height, and for the percent change in height and trunk diameter of A. rubrum, but not for end-ofseason trunk diameter (Table 4). However, the main effects of locations and container sizes were significant $(P \leq 0.001)$ for end-of-season trunk diameter on A. rubrum. Although linear increases in season-ending height (Figure 2a) and trunk diameter (Figure $2 b$ ) were observed, the percent change in tree height (Figure 2c) and trunk diameter (Figure $2 \mathrm{~d}$ ) were much greater in trees transplanted from smaller than from larger containers. This difference between container sizes is similar to the findings of Struve (2009), Gilman et al. (2010), and Lambert et al. (2010); however, this difference 
occurred much earlier in the establishment period than in the three growing seasons in Gilman et al. (2013). A mild interaction was present among container sizes and locations for season-ending height where differentials among smaller container sizes and those trees transplanted from larger containers were slightly less than those grown in Starkville (Figure 2a). This is likely due to a much greater percent change in height for A. rubrum from smaller containers following transplanting in College Station than in Starkville, although the general trend was similar between the two locations (Figure 2c). Across container sizes, seasonending trunk diameter of $A$. rubrum was greater $(P \leq 0.001)$ in Starkville $(4.49 \mathrm{~cm})$ than in College Station $(3.94 \mathrm{~cm})$. Extremes in percent change in tree height were more pronounced in the College Station data than the Starkville data. This is demonstrated by the $67.7 \mathrm{~cm}$ College Station growth in the \#3 container-grown trees paired with dieback of $12.5 \mathrm{~cm}$ on \#45 container-grown trees in College Station, compared to the $36.6 \mathrm{~cm}$ and $13.0 \mathrm{~cm}$ of growth in Starkville \#3 and \#45 container-grown trees, respectively (Figure 2c). Percent change in trunk diameter of \#3 container-grown A. rubrum during the growing season was greatest at both locations, with a more dramatic increase in percent change in trunk diameter exhibited in trees grown in Starkville than those in College Station (Figure $2 \mathrm{~d}$ ). Differences between locations may be attributable to differential environmental stresses. Conditions in Starkville were cooler and moister than in College Station (Table 3), thus potentially providing less heat stress and water demands despite irrigation being provided in College Station. These less stressful conditions may have mitigated some of the reportedly greater (Struve et al. 2000) impediments to establishment of larger container stock, resulting in fewer reductions in growth rates of larger A. rubrum stock in Starkville compared to College Station. Stress from deer grazing, greater susceptibility to drought, splash of irrigation water onto foliage, and greater fluctuations in watering resulted in mortality of four of the six transplanted trees from \# 1 containers in College Station. Hence, the \# 1 container size was disregarded for data analysis of A. rubrum in both College Station and Starkville.

Data suggest that aside from the \#1 containers, A. rubrum from smaller container sizes was less adversely affected by transplant shock than

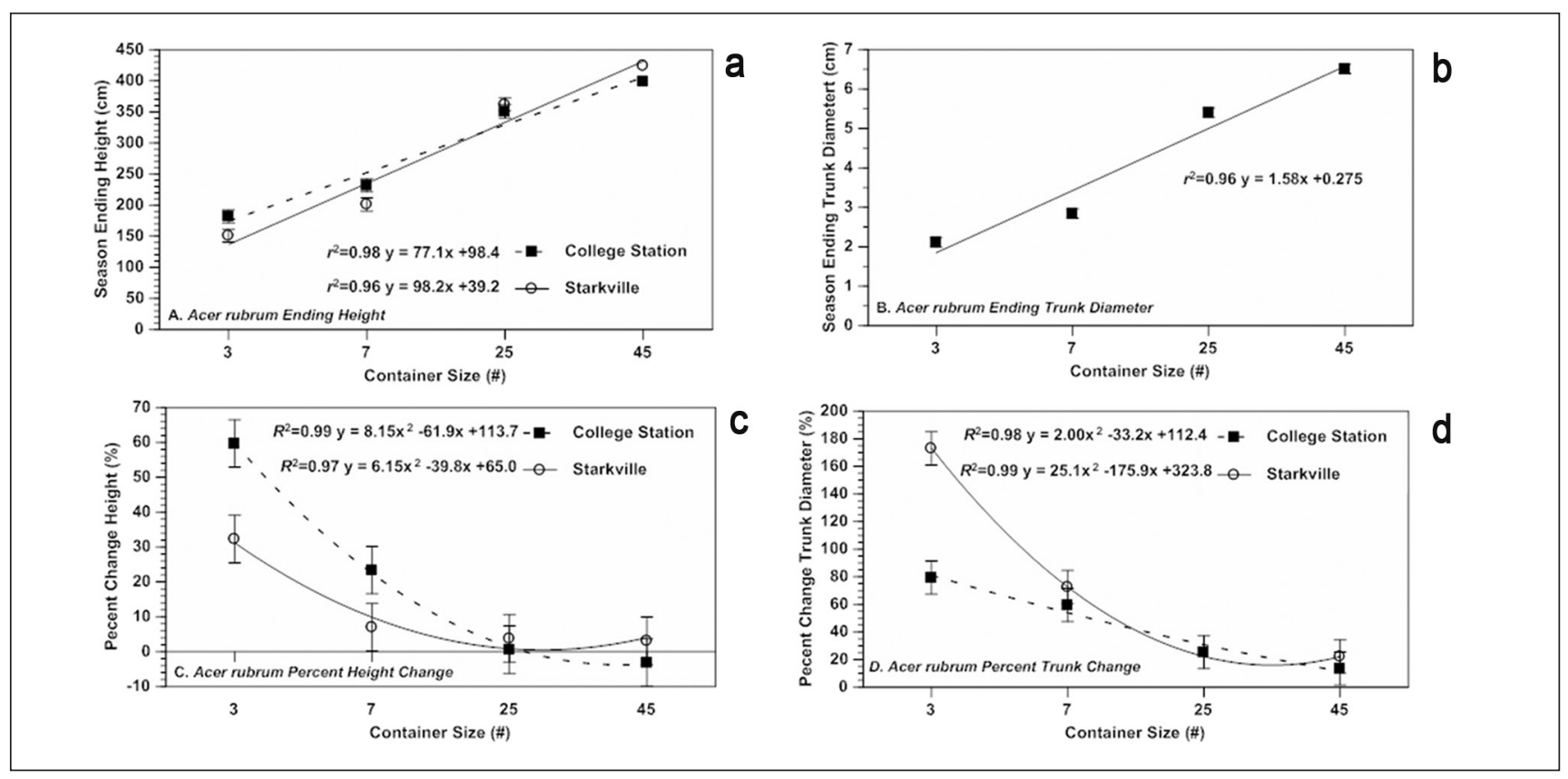

Figure 2. Interactions (a, c, d) for Acer rubrum var. drummondii among locations (College Station, Texas, and Starkville, Mississippi) and container sizes (\#3,\#7,\#25, and \#45) at transplant on end-of-season height (a), percent change in height (c), and trunk diameter (d) from transplant to the end of the first growing season, and the main effects of container sizes on end-of-season trunk diameter (b). Symbols represent means ( \pm standard errors) of $n=6$ for interactions (a, c, d) and $n=12$ for main effects (b). Best-fit regression equations were constructed for significant effects means and are presented where significant at $P \leq 0.05$. 
Table 4. Partial analysis of variance for initial growth of Acer rubrum var. drummondii 'Maroon', Vitex agnus-castus, and Taxodium distichum transplanted from five container sizes, \#1, \#3, \#7, \#25, and \#45 to field plots in College Station, Texas, and Starkville, Mississippi. Each species was treated as a separate but concurrent experiment, and arranged in the field in a completely random design.

\begin{tabular}{|c|c|c|c|c|c|}
\hline \multirow[t]{2}{*}{ Experiment } & \multirow[t]{2}{*}{ Effect } & \multicolumn{2}{|l|}{ Ending } & \multicolumn{2}{|l|}{ Percent change in: } \\
\hline & & $\begin{array}{l}\text { Trunk diameter } \\
\text { or canopy width }^{z}\end{array}$ & $\begin{array}{l}\text { Tree } \\
\text { height }\end{array}$ & $\begin{array}{l}\text { Trunk diameter } \\
\text { or canopy width }^{z}\end{array}$ & $\begin{array}{l}\text { Tree } \\
\text { height }\end{array}$ \\
\hline \multirow[t]{3}{*}{ Acer rubrum } & Location & $* * *$ & ns & $* * *$ & ns \\
\hline & Container size & $* * *$ & $* * *$ & $* * *$ & $* * *$ \\
\hline & Location $\times$ container size & ns & * & ** & * \\
\hline \multirow[t]{3}{*}{ Taxodium distichum } & Location & $* * *$ & ns & * & ns \\
\hline & Container size & $* * *$ & $* * *$ & $* * *$ & $* * *$ \\
\hline & Location $\times$ container size & * & ns & ns & ns \\
\hline \multirow[t]{3}{*}{ Vitex agnus-castus } & Location & ns & ns & ns & ns \\
\hline & Container size & $* * *$ & $* * *$ & $* * *$ & $* * *$ \\
\hline & Location $\times$ container size & ns & * & ns & ns \\
\hline
\end{tabular}

${ }^{\mathrm{z}}$ Indicates significance of trunk diameter for A. rubrum and T. distichum or canopy width for $V$. agnus-castus.

Notes: Single asterisk $\left({ }^{*}\right)=P \leq 0.05$; double asterisk $\left(^{* *}\right)=P \leq 0.01$; triple asterisk $\left.{ }^{* * *}\right)=P \leq 0.001$; ns $=$ not significant at $P \leq 0.05$.

the larger container sizes at both sites, but with less water stress and temperature stress at the Starkville site, \#3 container-grown trees performed even better than those in College Station.

\section{Taxodium distichum}

Interactions among container sizes and locations for $T$. distichum were significant $(P \geq 0.05)$ only for season-ending trunk diameter (Table 4). However, main effects of container size were significant for $T$. distichum season-ending height, percent change in trunk diameter and percent change in tree height $(P \leq 0.05)$. The main effect of locations was also significant for percent change in trunk diameter. End-of-season tree height (Figure 3a) and trunk diameter (Figure $3 \mathrm{~b}$ ) for T. distichum increased with increasing container size, but the percent change in both height (Figure 3c) and trunk diameter (Figure $3 \mathrm{~d}$ ) of $T$. distichum had a non-linear response. Peak percent change following transplant for $T$. distichum in both tree height and trunk diameter occurred from \#3 container-grown trees and trees from smaller containers had greater initial growth rates than those from larger \#25 and \#45 containers (Figure 3c; Figure 3d). Across container sizes, the percent increase in trunk diameter of $T$. distichum was considerably greater $(P \leq 0.05)$ in Starkville (142.6\%) than in College Station (101.2\%) during the first growing season after transplant.

Generally speaking, for A. rubrum and T. distichum, there was a largely positive growth response with smaller rather than larger container-grown trees, the lesser performance of T. distichum in \#1 container than in \#3 and the excessive mortality of transplanted \#1 container-grown A. rubrum suggest that there is a limitation to the positive impacts of smaller container sizes on transplant establishment. This could be due to susceptibility of \#1 container-grown trees to environmental effects, such as salt spray in the irrigation water, herbivory, or smaller biomass to withstand the vagrancies of climatic conditions. The more severe reductions in percent changes in height (Figure 3c) and trunk diameter (Figure 3d) suggest that trees grown in greater than \#7 containers exhibited little positive growth initially following transplant, likely due to less rapid recovery from transplant shock.

\section{Vitex agnus-castus}

Interactions among container sizes and locations were significant $(P \geq 0.05)$ only for the seasonending height (Figure $4 \mathrm{a}$ ) of $V$. agnus-castus. Although this interaction was statistically significant (Table 4), it was associated with very small magnitudes of differences in response among locations, and generally resulted in a similar pattern of response in season-ending height across locations (Figure $4 \mathrm{a}$ ). The main effects of container size were significant $(P \leq 0.05)$ for canopy width (Figure $4 \mathrm{~b}$ ), percent change in height (Figure $4 \mathrm{c}$ ), and percent change in canopy width (Figure 4d) of V. agnus-castus (Table 4). Vitex exhibited a nearly linear decrease in percent height and canopy width change with increasing container sizes (Figure 4c; Figure $4 \mathrm{~d}$ ), with the smaller sizes initiating greater proportional growth than the larger container 


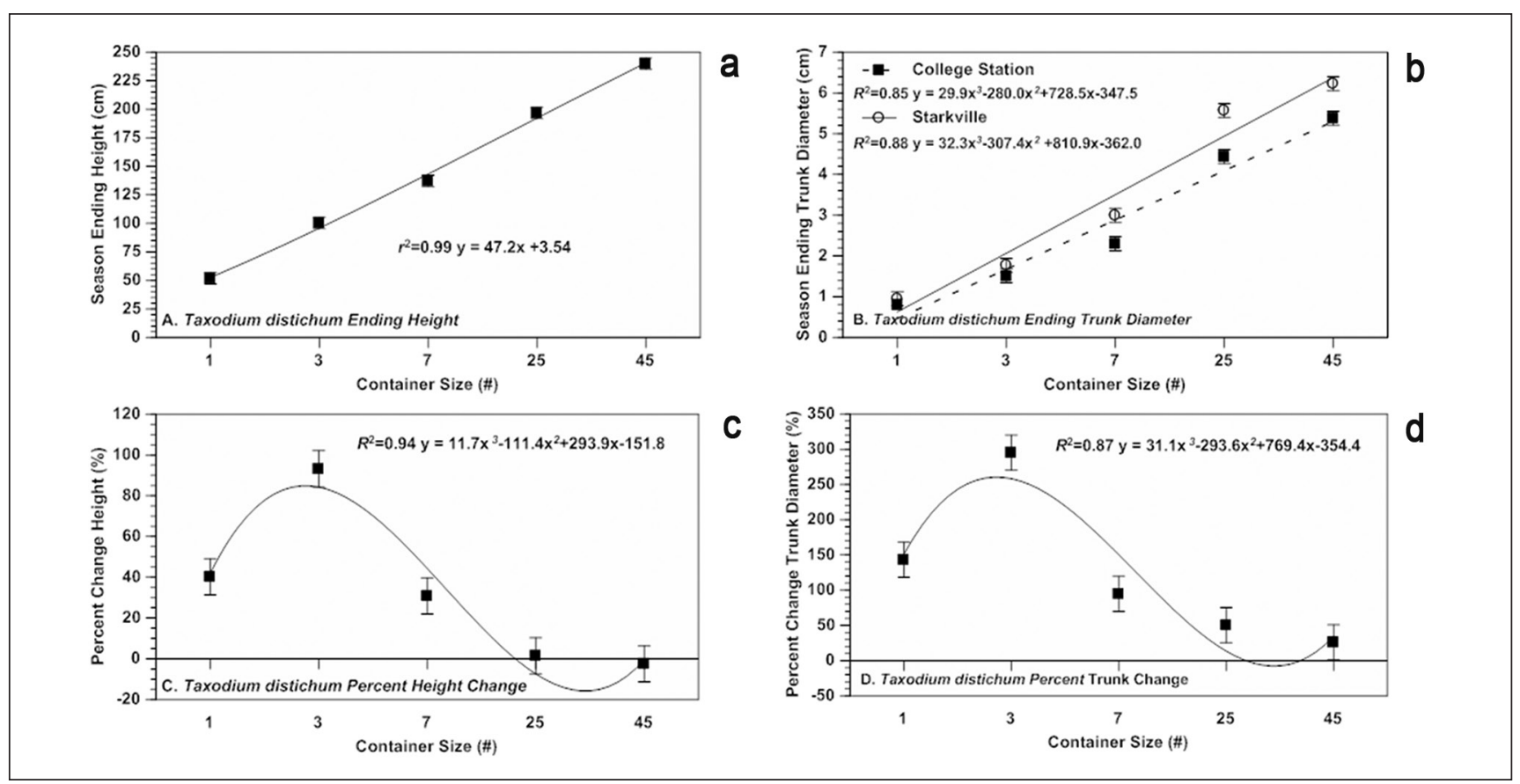

Figure 3. Interactions (b) for Taxodium distichum among locations (College Station, Texas, and Starkville, Mississippi) and container sizes (\#1, \#3, \#7, \#25, and \#45) at transplant on end-of-season trunk diameter (a) and the main effects of container sizes on end-of-season height (a), and percent change in height (c) and trunk diameter (d) from transplant to the end of the first growing season. Symbols represent means ( \pm standard errors) of $n=6$ for interactions (b) and $n=12$ for main effects (a, c, d). Best-fit regression equations were constructed for significant effects means and are presented where significant at $P \leq 0.05$.

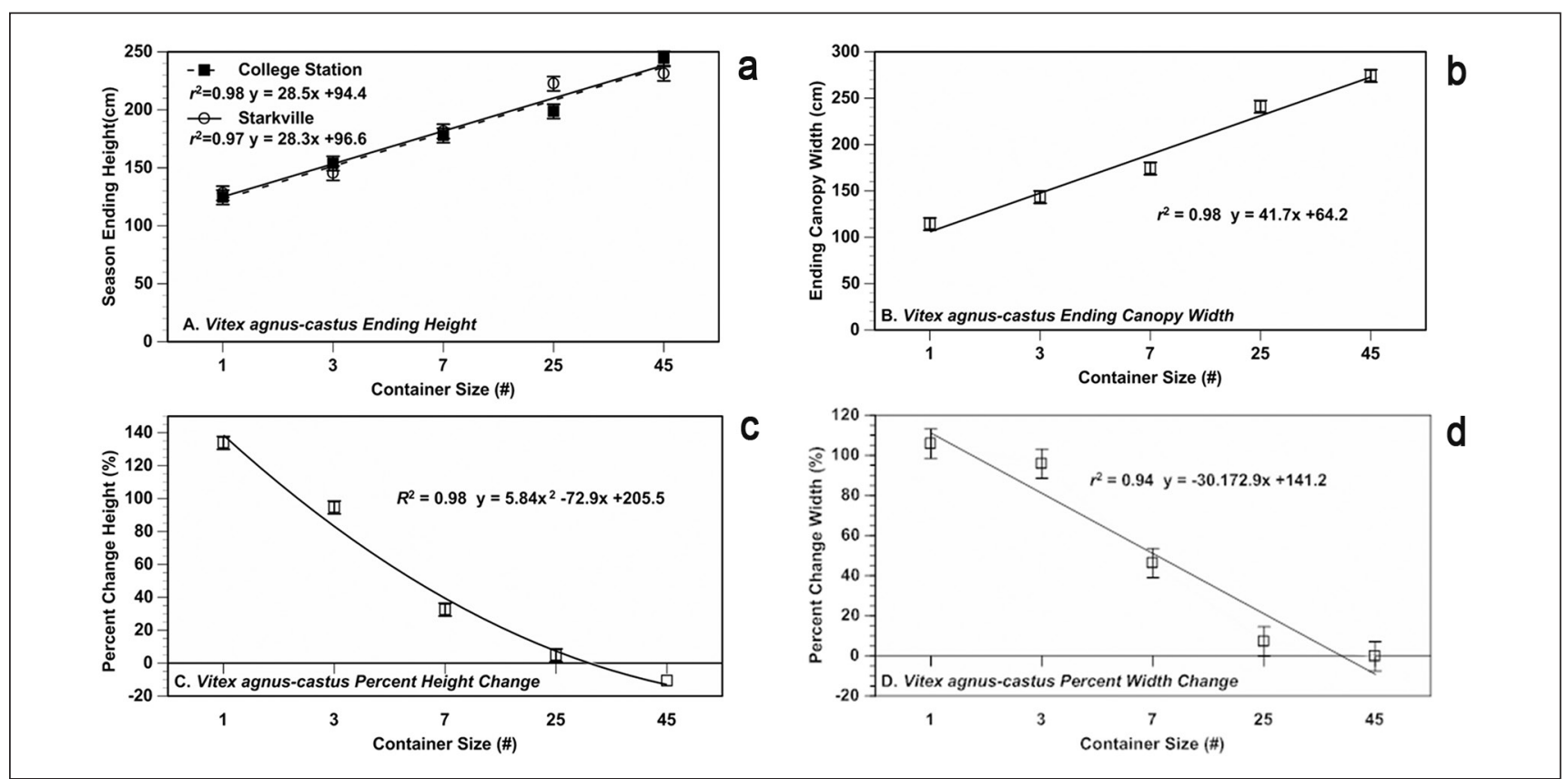

Figure 4. Interactions (a) for Vitex agnus-castus among locations (College Station, Texas, and Starkville, Mississippi) and container sizes (\#1, \#3, \#7, \#25, and \#45) at transplant on end-of-season height (a) and the main effects of container sizes on end-of-season trunk diameter (b), and percent change in height (c) and trunk diameter (d) from transplant to the end of the first growing season. Symbols represent means ( \pm standard errors) of $n=6$ for interactions (b) and $n=12$ for main effects (a, c, d). Best-fit regression equations were constructed for significant effects means and are presented where significant at $P \leq 0.05$. 
sizes. Data indicate trees in larger container sizes, in some cases, decreased in height during the initial growing season due to slight dieback. This can be seen in the \#45 container-grown trees (Figure 4a) in College Station with an ending height of $244.3 \mathrm{~cm}$, and in Starkville with $231.1 \mathrm{~cm}$, versus the original $266.2 \mathrm{~cm}$ in the nursery (Table 2). This is indicative of greater transplant stress in the larger container sizes at both locations.

Canopy width, rather than trunk diameter, was used as a growth measure for $V$. agnus-castus due to the variable trunk structure of $V$. agnuscastus. A curvilinear slope fit the effect of container sizes $\left(R^{2}=0.98\right)$ on canopy width (Figure $4 c)$. The slope indicated a greater growth difference among smaller size container-grown trees than the larger container-grown trees ( $\# 25$ and \#45). Similar to height, a slight decrease in width was measured in the Starkville \#45 containergrown trees at $268.2 \mathrm{~cm}$, versus the nursery 274.5 $\mathrm{cm}$, indicating nominal dieback. Smaller container sizes produced a positive change in width during the first growing season post-transplant, whereas even with irrigation, larger containergrown $V$. agnus-castus growth languished.

The lack of significance of locational effect for $V$. agnus-castus, is unique compared to the other two species (Table 4; Figure 2; Figure 3; Figure 4). However, this could potentially be explained by the documented wide environmental adaptation of $V$. agnus-castus as evidenced by its resistance to heat, drought, soil variability, and pests (Gilman and Watson 1994). Although it is drought tolerant once established, it will grow faster with supplemental water, especially during initial transplant establishment (Welch 2008). Root growth for V. agnus-castus occurs in larger quantities immediately following transplant and extends its roots farther during the initial season post-transplant than A. rubrum or T. distichum (Garcia 2015). Perhaps with irrigation, $V$. agnus-castus received adequate water at both locations and had appropriate sunlight and temperatures for optimal growth, explaining the lack of significance for location.

\section{CONCLUSION}

Container sizes of transplanted stock had a profound effect in initial establishment of all three species during the initial growing season after transplant across growth measures and at both locations (Figure 2; Figure 3; Figure 4). For A. rubrum and $T$. distichum, the best relative growth posttransplant was exhibited by \#3 container-grown trees, whereas the best growth rates of $V$. agnuscastus were from \#1 containers. Uniformly poor post-transplant growth was observed with \#25 and \#45 container-grown trees of all three species during initial post-transplant establishment (Figure 2; Figure 3; Figure 4). This confirms reports from Struve (2009) and Gilman et al. (2010) that reported quicker establishment from smaller-sized planting stock. Where locational effects were observed, with the exception of percent change in height growth of $A$. rubrum, greater growth was found in Starkville, where temperatures and rainfall were more moderate, suggesting that differential responses associated with container size may be of greater importance in locations with more stressful growing conditions than in those with favorable climates. Additional work is needed to determine if these differences among container sizes persist into the future, at some point resulting in similarly sized landscape plants from a range of container sizes, and to determine if root growth or other drought mechanisms are differentially influenced.

Documentation of the differences in container sizes by environment will prove useful as containergrown trees gain momentum in the industry. This research will allow homeowners, landscapers, and arborists to correctly select the container size that is best suited for transplant stress for their region, as well as to predict growth responses.

\footnotetext{
Acknowledgments. The College Station portion of this study was included as part of a thesis written in partial fulfillment of the requirements for the M.S. degree by L.M. Garcia. This work was supported in part by funds from Texas A\&M AgriLife Research and the Tree Research and

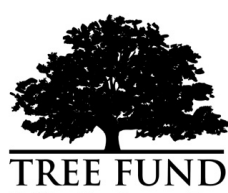
TREE FUND Education Endowment (TREE) Fund. Mention of a trademark, proprietary product, or vendor does not constitute a guarantee or warranty of the product by the authors, Texas A\&M University, or Texas A\&M AgriLife Research, and does not imply its approval to the exclusion of other products or vendors that also may be suitable.
} 


\section{LITERATURE CITED}

Abrams, M.D., and M.E. Kubiske. 1990. Photosynthesis and water relations during drought in Acer rubrum L. genotypes from contrasting sites in central Pennsylvania. Functional Ecology. 5(6):727-733.

American Association of Nurserymen. 2004. American standards for nursery stock. ANSI Z60.1-2004. American Association of Nurserymen, Washington D.C., U.S.

Arnold, M.A. 2004. Challenges and benefits of transplanting large trees: An introduction to the workshop. HortTechnology 15:115-117.

Chapin, III, F.S., A.J. Bloom, C.B. Field, and R.H. Waring. 1987. Plant responses to multiple factors. BioScience 37:49-57.

Garcia, L.M. 2015. Post-transplant establishment and economic value of three tree species from five container sizes. Texas A\&M University, College Station, Texas, U.S.

Gilman, E.F., and M.E. Kane. 1990. Root growth of red maple following planting from containers. HortScience 25:527-528.

Gilman, E.F., and D.G. Watson. 1994. Environmental Horticulture Department, Florida Cooperative Extension Service, Institute of Food and Agricultural Science, University of Florida. Vitex agnus-castus; Chastetree Fact Sheet ENH-821. <http://edis.ifas. ufl.edu/st664>

Gilman, E.F., and R.C. Beeson. 1996. Nursery production method affects root growth. Journal of Environmental Horticulture 14:88-91.

Gilman, E.F., R.J. Black, and B. Dehgan. 1998. Irrigation volume and frequency and tree size affect establishment rate. Journal of Arboriculture 24:1-9.

Gilman, E.F., C. Harchick, and M. Paz. 2010. Effect of tree size, root pruning, and production method on establishment of Quercus virginiana. Arboriculture \& Urban Forestry 36:183-190.

Gilman, E.F., and F. Masters. 2010. Effect of tree size, root pruning and production method on root growth and lateral stability of Quercus virginiana. Arboriculture \& Urban Forestry 36:281-291.

Gilman, E.F., J. Miesbauer, C. Harchick, and R.C. Beeson. 2013. Impact of tree size and container volume at planting, mulch, and irrigation on Acer rubrum L. growth and anchorage. Arboriculture \& Urban Forestry 39:173-181.

Kalmbach, K.L., and J.J. Kielbaso. 1979. Residents' attitudes toward selected characteristics of street tree plantings. Journal of Arboriculture 5:124-129.

Lambert, B.B., S.J. Harper, and S.D. Robinson. 2010. Effect of container size at time of planting on tree growth rates for baldcypress [Taxodium distichum (L.) Rich], red maple (Acer rubrum L.) and longleaf pine (Pinus palustris Mill.). Arboriculture \& Urban Forestry 36:93-99.

Lauderdale, D.M., C.H. Gillam, D.J. Eakes, G.J. Keever, and A.H. Chappelka. 1995. Tree transplant size influences post-transplant growth, gas exchange, and leaf water potential of 'October Glory' red maple. Journal of Environmental Horticulture 13:178-181.

Maco, S.E., and E.G. McPherson. 2003. A practical approach to assessing structure, function, and value of street tree populations in small communities. Journal of Arboriculture 29:84-97.

Missouri Botanical Garden. 2015. Mechanical Damage. <www. missouribotanicalgarden.org/gardens-gardening/your-garden/ help-for-the-home-gardener/advice-tips-resources/pests-andproblems/environmental/mechanical.aspx>
Nowak, D.J., R. Hoehn, and D. Crane. 2007. Oxygen production by urban trees in the United States. Arboriculture \& Urban Forestry 33:220-226.

Schroeder H., J. Flannigan, and R. Coles. 2006. Residents' attitudes toward street trees in the UK and U.S. communities. Arboriculture \& Urban Forestry 32:236-246.

Struve, D.K., L. Burchfield, and C. Maupic. 2000. Survival and growth of transplanted large-and small-caliper red oaks. Journal of Arboriculture 26:162-169.

Struve, D.K. 2009. Tree establishment: A review of some of the factors affecting transplant survival and establishment. Arboriculture \& Urban Forestry 35:10-13.

Teskey, R.O., and T.M. Hinckley. 1986. Moisture: Effects of water stress on trees. pp. 9-33. In: T.C. Hennessey, P.M. Dougherty, and J.D. Johnson (Eds.). Stress physiology and forest productivity. Kluwer Academic Publishers, Hingham, Massachusetts, U.S.

Watson, G.W., and E.B. Himelick. 2013. The Practical Science of Planting Trees. International Society of Arboriculture, Champaign, Illinois, U.S.

Watson, W.T. 2004. Influence of tree size on transplant establishment and growth. HortTechnology 15:118-122.

Welch, W.C. 2008. Texas AgriLife Extension Service Horticulture Update: Vitex or Chaste Tree. <http://aggie-horticulture.tamu. edu/newsletters/hortupdate/2008/jun08/Vitex.html>

Lauren M. Garcia-Chance (corresponding author)

Graduate Research Assistant

Texas A\&M University

College Station, Texas, U.S.

Michael A. Arnold

Professor and Associate Department Head

Texas A\&M University

College Station, Texas, U.S.

Geoffrey C. Denny

Assistant Professor

Mississippi State University

Starkville, Mississippi, U.S.

Sean T. Carver

Graduate Researcher

Texas A\&M University

College Station, Texas, U.S.

Andrew R. King

Graduate Fellow

Texas A\&M University

College Station, Texas, U.S. 
Résumé. Les impacts de deux environnements distincts suite à leur transplantation furent testés sur des arbres cultivés dans cinq dimensions de contenants en pépinière afin de déterminer les différences dans la croissance initiale suivant leur plantation. Des Vitex agnus-castus L., des Acer rubrum L. var. drummondii (Hook. \& Arn. ex Nutt.) Sarg., et des Taxodium distichum (L.) Rich. furent cultivés dans des pots de $3,5 \mathrm{~L}\left(\mathrm{n}^{\circ} 1\right)$, de $11,7 \mathrm{~L}\left(\mathrm{n}^{\circ} 3\right)$, de $23,3 \mathrm{~L}\left(\mathrm{n}^{\circ} 7\right)$, de 97,8 L ( $\left.{ }^{\circ} 25\right)$, et de 175,0 L (\# 45) ont été plantés en début d'été dans des parcelles de terrain situées à College Station, au Texas, et à Starkville, au Mississippi, aux États-Unis. Les mesures de la hauteur, du diamètre du tronc et de la largeur du houppier ont été enregistrées après la production en pépinière et à la fin de la première saison de croissance afin de déterminer la croissance initiale lors de l'établissement en pleine terre. La croissance des A. rubrum et des T. distichum fut significativement $(\mathrm{P} \leq 0,05)$ affectée par les interactions entre la dimension des pots et l'environnement auquel ils étaient exposés, tandis que les V. agnus-castus n'ont pas démontrés de différence marquée entre les environnements, mais ont été affectés par la dimension des contenants. Parmi toutes les espèces et les emplacements, les arbres transplantés provenant des contenants de plus petite dimension montrèrent une plus grande variation positive liée à la croissance que les arbres provenant de contenants de plus grande dimension. Un plus grand pourcentage de variation dans les mesures de croissance pour les contenants de plus petite dimension suite à la première saison de croissance peut indiquer une plus rapide période de reprise de croissance par rapport aux arbres provenant de contenants de plus grande dimension. Là où des réactions différentielles aux conditions environnementales se sont produites, de manière prépondérante les effets bénéfiques des pots de plus petite dimension sur létablissement des jeunes arbres furent accentués lorsque les conditions du milieu devenaient plus éprouvantes.

Zusammenfassung. Bei Bäumen, die in fünf verschiedenen Pflanzcontainergrössen gezogen wurden, testeten wir die Einflüsse von zwei post-transplante Standortbedingungen, um die Unterschiede im ersten Wachstum nach der Verpflanzung zu bestimmen. Vitex agnus-castus L., Acer rubrum L. var. drummondii (Hook. \& Arn. ex Nutt.) Sarg., und Taxodium distichum (L.) Rich. gezogen in 3.5 L (\#1), 11.7 L (\#3), 23.3 L (\#7), 97.8 L (\#25), und 175.0 L (\#45) Container wurden im Frühsommer in Freilandbeete in College Station, Texas, und Starkville, Mississippi, U.S. verpflanzt. Messungen der Höhe, des Stammdurchmessers und der Kronenbreite wurden nach dsr Baumschulproduktion und dem Ende der ersten Wachstumsperiode aufgezeichnet, um das erste Wachstum während der Standortetablierung zu bestimmen. Das Wachstum von A. rubrum und T. distichum war signifikant $(P \leq 0.05)$ beieinflusst durch die Interaktionen zwischen Containergrösse und Umgebung, während $V$. agnus-castus keine Unterschiede bei den verschiedenen Umgebungen demonstrierte aber durch die Containergrössen beeinflusst war. Unter allen Arten und Standorten zeigten die Bäume aus der Verpflanzung von kleinen Containern eine grössere prozentuale Veränderung im Wachstum als die Bäume aus grösseren Pflanzcontainern. Eine grössere prozentuale Veränderung im Wachstum bei den Bäumen aus der Verpflanzung von kleinen Containern könnte eine schnellere Adaption an die Standortbedingungen bedeuten als bei Bäumen aus grösseren Pflanzcontainern. Wo unterschiedliche Reaktionen auftraten, wurden die vorteilhaften Auswirkungen der kleineren Pflanzcontainer auf die Entwicklung nach der Standortetablierung hauptsächlich mit stärkeren Stressbedingungen während der Etablierung erklärt.
Resumen. Los efectos de dos ambientes post-trasplante se pusieron a prueba en los árboles que crecen en cinco tamaños de contenedores de vivero para determinar las diferencias en el crecimiento inicial después del trasplante. Vitex agnus-castus L., Acer rubrum L. var. drummondii (Hook. \& Arn. ej Nutt.) Sarg., y Taxodium distichum (L.) Rich., crecidos en contenedores de 3,5 L (\# 1), 11,7 L (\# 3), 23,3 L (\# 7), 97,8 L (\# 25), y 175,0 L (\# 45), fueron trasplantadas a principios de verano en parcelas en el campo del College Station, Texas, y Starkville, Mississippi, Estados Unidos. Se tomaron mediciones de altura, diámetro del tronco y anchura de copa después de la producción en vivero y al final de la primera temporada de crecimiento para determinar el crecimiento inicial durante el establecimiento en el paisaje. Los crecimientos de $A$. rubrum y $T$. distichum fueron significativamente afectados $(\mathrm{P} \leq$ $0,05)$ por las interacciones entre los tamaños de los envases y ambientes, mientras que $V$. agnus-castus no demostró una diferencia entre los ambientes, pero se vieron afectados por el tamaño de los contenedores. A través de todas las especies y los lugares, los árboles trasplantados de tamaños de contenedores más pequeños mostraron un mayor porcentaje de cambio en el crecimiento que los árboles más grandes de contenedor. Mayor porcentaje de cambio en las medidas de crecimiento de los árboles de contenedores de tamaño más pequeño durante la primera temporada de crecimiento puede indicar un tiempo de establecimiento más rápido en comparación con los árboles de contenedores más grandes. Donde se produjeron las respuestas diferenciales a los ambientes, sobre todo los efectos beneficiosos de los tamaños de los envases más pequeños en el establecimiento después del trasplante se acentuaron las condiciones de establecimiento más estresantes. 